\title{
The Brazilian Stock Market Indicator: Determinants to Measure Variation and Direction
}

\author{
Jorge Luis Sanchez Arevaloํㅜ, Gabriela Moreira de Souza ${ }^{2}$, Rodrigo Malta Meurer ${ }^{3}$ \\ ${ }^{123}$ Federal University of Mato Grosso do Sul, Brazil
}

\begin{abstract}
The volatility has a great influence on agents' decision-making, therefore, measuring the degree and effect of the determining factors of the stock market indicator is of paramount importance. The study, based on the premise that assets with greater weight in the portfolio, as well as the foreign currency (dollar) quotation, can serve as predictors to assess the volatility of the indicator. For this purpose, an error correction model - VEC was used, starting from four explanatory variables defined and theoretically supported. The results show the importance of the autoregressive method, which is manifested by means of significant statistics to explain the variation and direction of Ibovespa. Although the importance of oil, iron ore and the dollar are determining variables, other factors such as cooperation agreements and / or stimuli aimed at the recovery of the economy cannot be neglected.
\end{abstract}

Keywords - Stock exchange, determining factors, vector error correction model - VEC.

JEL: $G 1, G 15, C 22$

\section{INTRODUCTION}

The last year (2019), the world economy grew at the weakest pace recorded since the global financial crisis of a decade ago, reflecting common influences between countries and specific national factors. Brazil, for example, suffered some pressures that came from specific national weaknesses [17]. However, at the beginning of the year, financial markets were driven by a broad sense of optimism, supported by monetary policies to reduce trade tensions and attempts to stabilize the global economy. However, COVID-19 has changed all that, and the economy is in the midst of a historic decline in the stock markets and volatility levels, which were last seen only during the 2008 global financial crisis [17].

Given the above, it is worth mentioning that there are some thermometers to monitor the evolution of prices within the stock exchanges. In this context, B3 - Brazil, (São Paulo Stock Exchange), which is the main stock market in Brazil, which emerged in 2017, as a result of the combination of BMF \& BOVESPA and CETIP, in which publishes the Ibovespa index daily [5]. The Ibovespa index, in turn, is the main index of the Brazilian stock exchange, which was created in 1968 and today is considered a reference around the world. It is the result of a theoretical portfolio of assets and the main performance indicator of the shares traded at B3 bringing together the most important companies in the Brazilian capital market [4]. It should also be noted that the indices fulfill three main functions: act as indicators of market price changes, serve as a parameter for future performance evaluations and be a trading instrument in the future market [6].

It is noted, therefore, that this index is extremely important, as it shows in only one economic scenario, what was the behavior of the most traded shares on the Stock Exchange, being an indicator of average performance of the quotations of the assets that has greater negotiability and representativeness in the Brazilian market, reflecting changes in assets over the term. Highlighting the scenario of both social and economic uncertainties that the world experiences in 2020, it is possible to identify an eminent crisis in companies, which cause changes in the Ibovespa index and also in the Ibovespa Future, as highlighted in a study by Maciel [22], one of the most relevant future trading contracts.

Still on the Ibovespa indicator, one of the objectives is to reflect the general behavior of investments in the stock market, taking into account the performance of the shares of the main companies in the country, such as 
Petrobras, Vale and Ambev, among others. In this way, Ibovespa is composed of, on average, 70 companies, with Vale S.A. and Petrobras S. A. having the highest percentage of participation in the Ibovespa portfolio [4].

In view of this, it is important to take into account aspects that influence the behavior of the indicator, such as the case of events related to the system's risk. In the first quarter of 2020, the world economy was shaken by the COVID-19 effect, which has an effect on macroeconomic variables, such as: The Gross Domestic Product GDP [29], be it the interest rate [15, 12], or the exchange rate [24, 14], which are variables that change during a period of crisis. In addition, in the Brazilian case, political noises cannot be neglected, which affects the intent of foreign capital investment.

Thus, the study starts from the premise that events such as those mentioned above determine the behavior of the economy and companies, consequently, this effect is reflected in the stock market indicator. To determine this effect, the study uses the Error Prediction Model - VEC, to analyze the effect and intensity that certain variables cause the indicator in the short and long term.

\section{A. Theoretical Framework}

\section{LITERATURE REVIEW}

From the theoretical point of view, it is understood that the financial market reflects the economic reality. Specifically, the stock exchange indicator of a given country reflects the economic and political reality, that is, the financial market measured by the stock exchange indicator serves as a mediator of variables of a political and economic nature.

It is evident that the stock exchange variation caused by several factors linked to the business environment affects the decisions of investors. The linked aspects that affect the business environment include public information, as well as price formation given by the market [2, 28, 32]. In case of information failures in these mentioned elements, insecurity arises, and the market becomes unattractive or unfavorable for the investment $[29,7,1]$.

The table 1, describes several studies that highlight the importance of prices and information as a determining factor in the business environment. The integration, as well as, the existence of transmission channels and volatilities that are passed on between the markets stands out. This implication influences the valuation of assets, as well as in the formation of investment portfolios. In addition, the more integrated the markets are, the transmission intensity grows in the short term, something that can serve as a basis for long-term trend arguments. In this sense, Auto-regressive Vector methodologies gained popularity in the academic world for the analysis of time series.

Table 1 - Studies aimed at analyzing the volatility of stock exchanges using the Autoregressive Vector methodology mentioned in the text.

\begin{tabular}{ccccc}
\hline Author & Problem & Period & Method & Findings \\
\hline \hline $\begin{array}{c}\text { Shahrestani } \\
\text { and Rafei }\end{array}$ & $\begin{array}{c}\text { Global oil price } \\
\text { fluctuations have a } \\
\text { significant impact on } \\
\text { various areas of the } \\
\text { financial sector especially } \\
\text { the stock market }\end{array}$ & $\begin{array}{c}2002 \\
/ 2017\end{array}$ & $\begin{array}{c}\text { Vector Autoregressive } \\
\text { (VAR) }\end{array}$ & $\begin{array}{c}\text { The shocks have both } \\
\text { positive and negative impacts } \\
\text { on the Tehran }\end{array}$ \\
$\begin{array}{c}\text { Alqahtani, et } \\
\text { al. }\end{array}$ & $\begin{array}{c}\text { Impact of news on } \\
\text { international stock } \\
\text { markets }\end{array}$ & $2001 /$ & The standard and nonlinear \\
ARDL models & $\begin{array}{c}\text { Significant and negative } \\
\text { impacts on stock market } \\
\text { returns }\end{array}$ \\
\hline $\begin{array}{c}\text { Uzo-Peters, } \\
\text { Laniran and } \\
\text { Adenikinju }\end{array}$ & $\begin{array}{c}\text { The impact of Brent oil } \\
\text { price shocks on oil related } \\
\text { stocks }\end{array}$ & $2007 / 2$ & $\begin{array}{c}\text { R) model with the impulse } \\
\text { response function and the } \\
\text { forecast variance } \\
\text { decomposition error }\end{array}$ & $\begin{array}{c}\text { The oil price shocks have a } \\
\text { negative impact on Nigerian } \\
\text { oil and gas company stocks }\end{array}$ \\
\hline
\end{tabular}


Debata and Mahakud

The relationship between monetary policy and individual stock liquidity in an emerging stock market
Vector autoregressive (VAR)-Granger causality test, impulse response functions and variance decomposition
The monetary policy significantly Granger-causes stock liquidity, and the expansionary monetary policy characterized by low interest rate and higher money supply is positively associated with individual stock liquidity

The foreign investment is neither affected by exchange rates nor by stock Exchange movements, but exchange rates and stock Exchange returns are affected by foreign investment

Specifically, when speaking of the Brazilian economic context in 2017, the Brazilian economy again experienced a growth in the economy's income, after two years of recession, in 2015 and 2016. Since the year 2018, the stock market has had a high performance, growing trend, reflecting among other aspects, the growing economy. Meanwhile, at that time, the political environment stands out as the increase in corruption and internal problems related to the increase in prices of two fuels (effect of the oil price war between OPEC and Russia) that triggered a wave of protests by two truckers. These events will affect the performance of the market indicator of the economy, which shows that evidences that the financial market, specifically the stock market, is a key factor for the growth of a capitalist economy.

A variable that cannot be neglected is the dollar. When a domestic currency is devalued, there must be a change in the structure of the investment and in the debt of companies, considering or effect that this variable (exchange rate) exercises on assets. By theoretical principle, the existence of a causal relationship between the exchange rate and the stock index is considered, depending on the appreciation/devaluation of the domestic money, the investment intentions become favourable [25, 26, 21]. In the case of the Brazilian scenario, the domestic currency has lost a lot of purchasing power, to the dollar since 2018, and with an economy growing below potential, the Central Bank responds with expansive monetary policies to stimulate growth.

\section{B. The Study Variables}

The Ibovespa index is the main indicator, which includes companies that have shares traded in Brazil. In a way, changes that occur in the business environment and that cause changes in the exchange rate, interest rate, inflation, among others, affect companies, and in turn also the Ibovespa index [23, 27]. Linked to this, political noises in the Brazilian environment should be considered, which generate uncertainty for investors.

As shown in figure 1, since 2018 the Ibovespa index has grown significantly. For the period under study, political and market events as the indicator's behavior moved less intensely when compared to the crisis experienced in the first quarter 2020. Regarding market events, there is a great oscillation in oil prices causing an excess supply. On the political side, the case known as the Joesley day, which caused a collapse of the Brazilian stock market in 2017 and which spread until 2018. In addition, the "lava jato" case involving several politicians from the Brazilian scene, as well as companies linked to the stock exchange of values. 


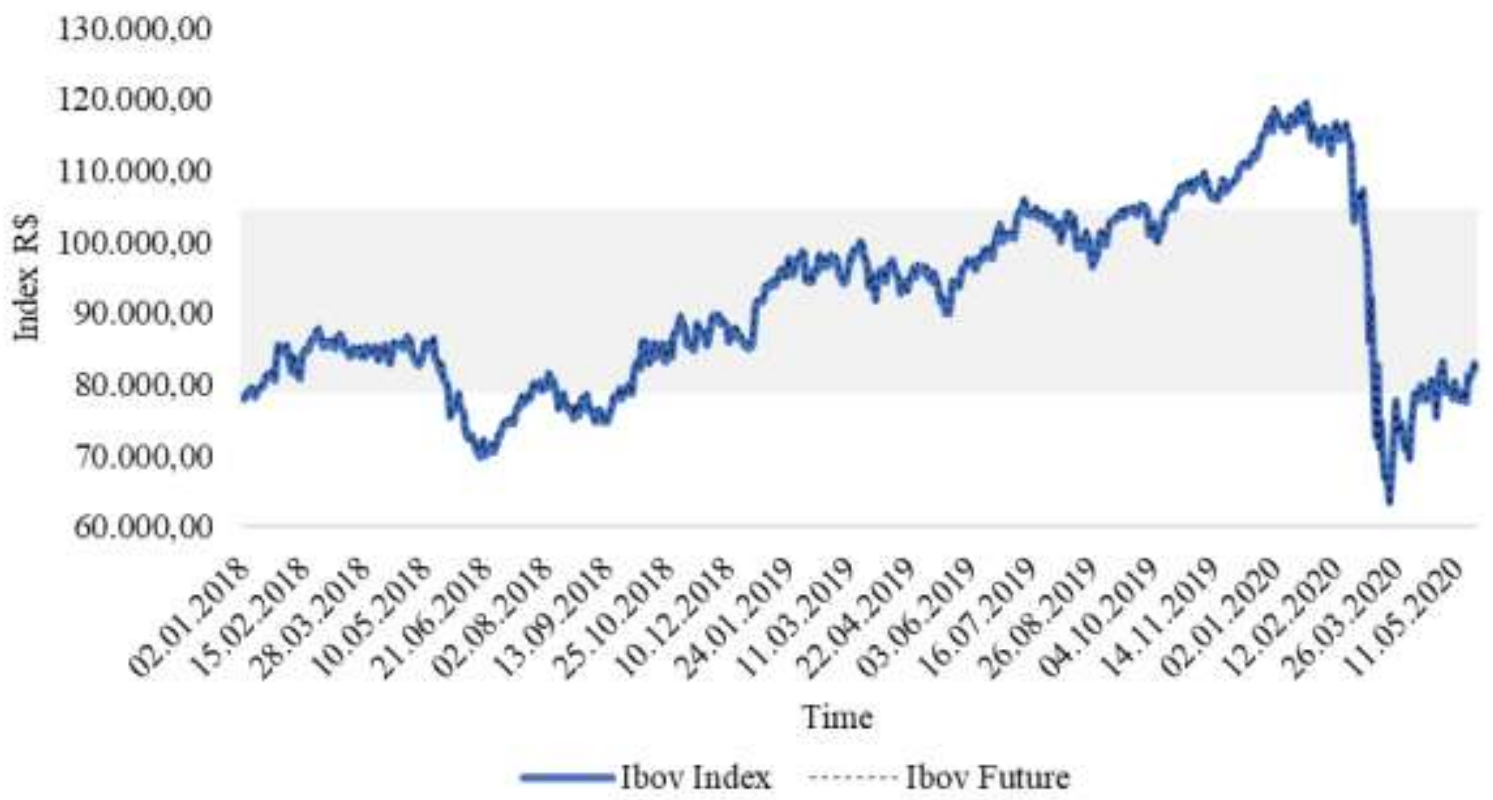

Fig. 1 - Quotation of the IBOVESPA index spot and future. Value in R\$ - Brazilian real. Source: Economatica (2020).

When analyzing the figure, an average line was drawn in this period for both indices (cash indicator and future indicator), it is possible to notice, a great relationship between the variables, evidently, the cash market reflects the future market. For the analyzed interval, the effect of the crisis in the first quarter of 2020 caused a major negative effect on the market, thus contracting the economy.

On the theoretical side, it is understood that the future market prices the spot market, considering the rationality of the investor to anticipate possible events in the market. Studies such as those by Talbi, Peretti and Belkacem [31]; Bernal-Ponce, Castillo-Ramirez and Venegas-Martinez [3]; Holmes and Otero [16] reinforce the above argument. Evidently, there is a strong long-term relationship between the spot market and the future and in the case of the Ibovespa indicator it is notorious.

The figure 2 depicts the quotes of VALE S.A. The company Vale SA, created as Company Vale do Rio Doce (CVRD), in 1942 in the region of Itabira, Minas Gerais, was created to ensure that the international market had access to the rich iron ore deposits, and to create the material bases that made it possible to meet the industrialization project in the country, since in 1942, after years of controversy, there was a shift of attention from precious minerals to industrial minerals. Also, Vale, is one of the most important companies in the Brazilian scenario and with the greatest weight on the Ibovespa indicator portfolio, corresponding to $11.14 \%$ of the participation in the index, according to the calculation of the portfolio on May 25, 2020 [4].

In the first quarter of 2020, the impacts of COVID-19 strongly affected the ore sector, which soon recovered. The international ore prices (TIOc1) and the great demand for the product from China explain the asset's appreciation in this period (See figure 2). 


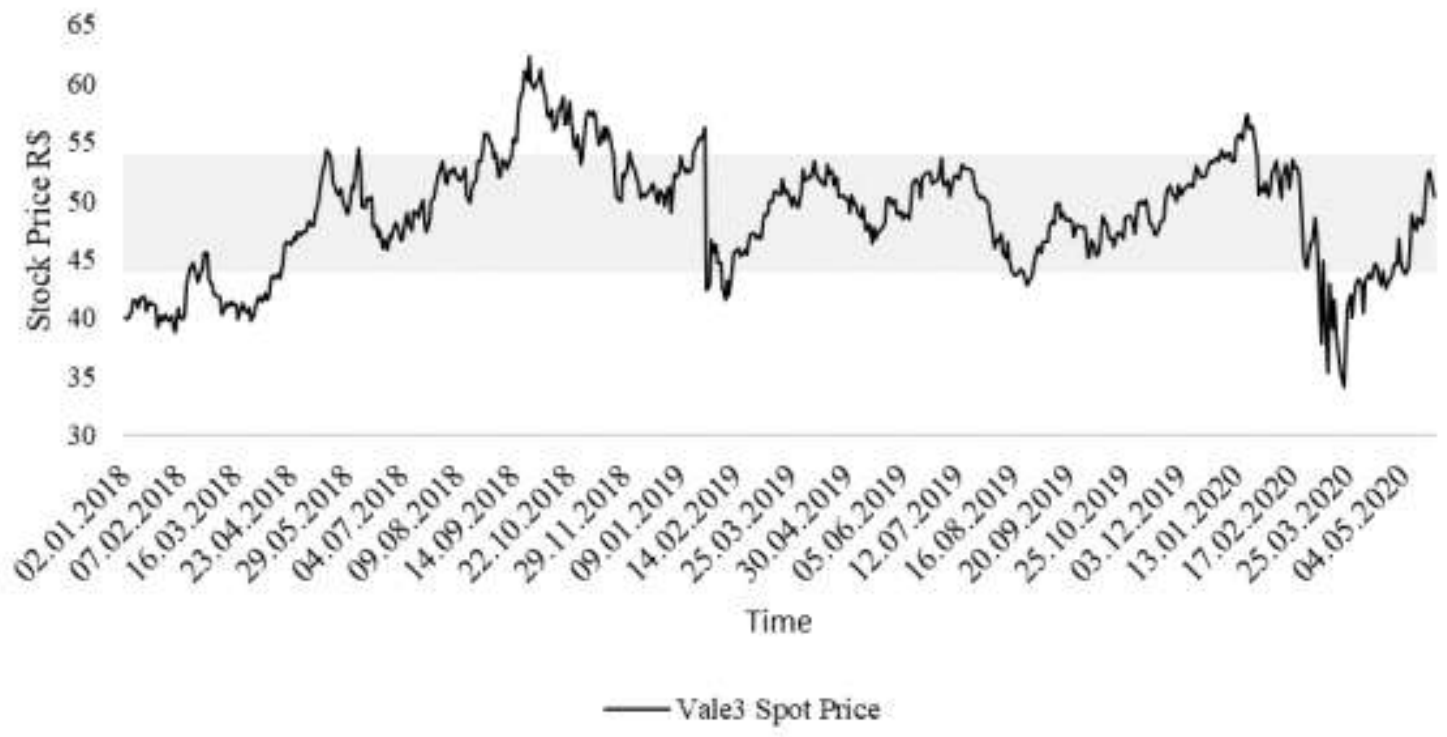

FIG. 2 - Spot price of Vale. Value in R \$ - Brazilian real.

Source: Economatica (2020).

The figure 3, is show the prices of Petrobras Preferred shares and the future of Oil Brent. Petrobras is one of the most important companies in Brazil, with a 5.68\% share in the Ibovespa index portfolio. The Future Brent oil serves as an international reference for Petrobras stock quotes. In the first quarter of 2020, the effects of COVID-19 were notorious in the sector (see figure 3 ).

Petrobras during 2018 had a lot of volatility due to several internal and external factors that affected the price of oil. When talking about the Brazilian scenario, there are cases involving the "lava jato" operation, which in addition to interfering with the Ibovespa index, also disturb Petrobras' share prices. Coupled with this, there was a trade war over international oil prices between OPEC and Russia. The effects of oil prices on the domestic market were notorious, such as the increase in transport tariffs and the increase in transport costs, basic products become more expensive, especially consumer goods.

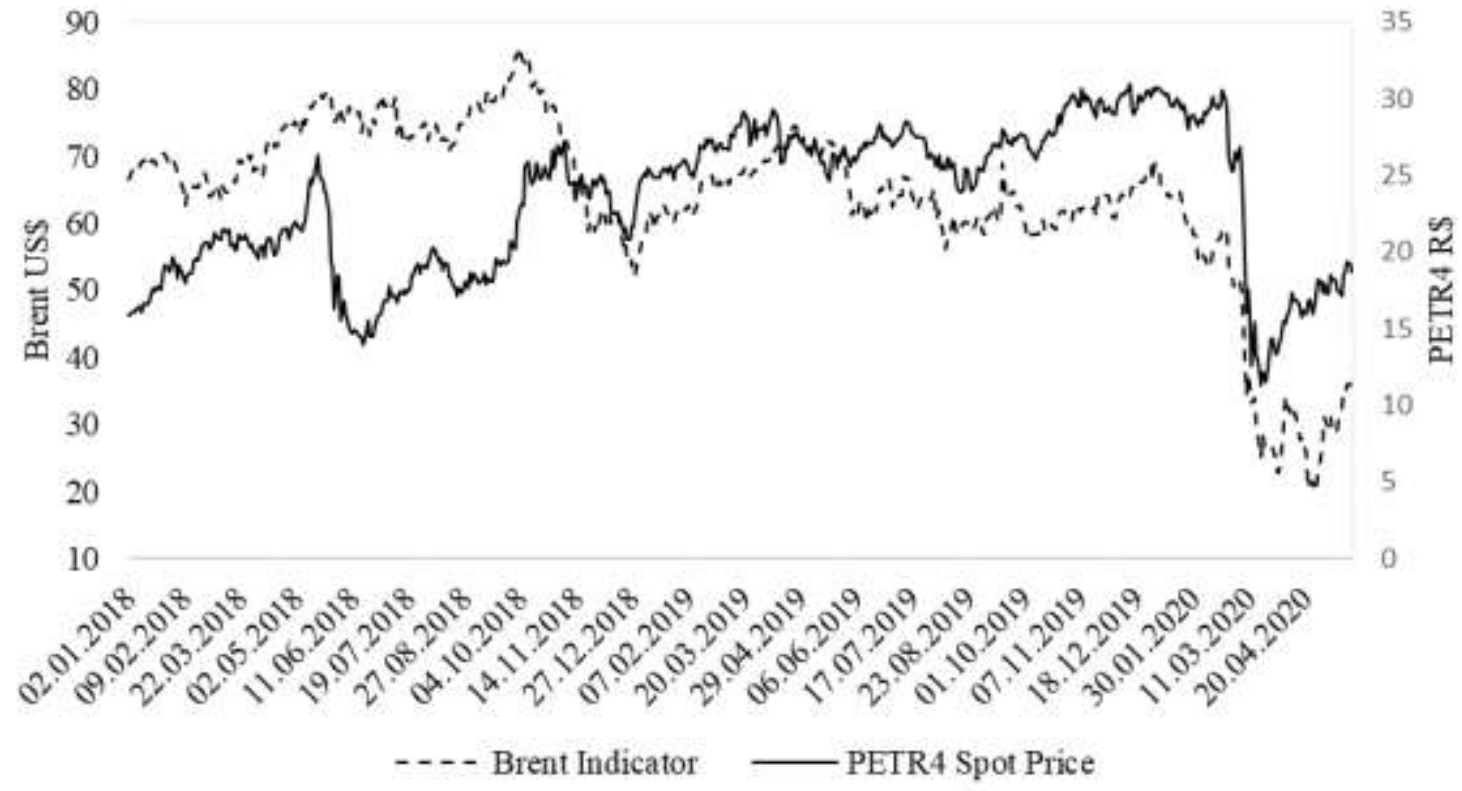

FIG. 3 - Spot price of Petrobras (R\$) and Brent Future (US\$).

Source: Economatica (2020). 


\section{A. The model, procedures and source}

\section{METHODOLOGY}

In all-time series analysis, one must first verify the order of integration of the series and, based on this information, identify whether the series has a unitary root or whether it is stationary in level. Among the various tests used to assess the stationarity of a time series, there is the Dickey-Fuller, such a procedure was proposed by Fuller [13] and complemented by Dickey and Fuller [8,9] which is known as the Dickey test - Augmented Fuller (ADF), which is widely used in the literature to test for the presence of unit root, which constitutes a nonstationary situation (1).

$$
\Delta Y_{t}=\alpha+\beta T+\delta Y_{t-1}+\sum_{i=1}^{n} \Delta Y_{t-i}+\varepsilon_{t}
$$

On what $\Delta$ is the first difference operator $\left(\Delta Y_{t}=Y_{t}-Y_{t-1}\right) ; \alpha$ the intercept term; ${ }^{T}$, trend; $\delta(=\rho-1)$, test coefficient of the presence or absence of unit root; $\Delta Y_{t-1}$, dependent variable itself differentiated and lag, whose objective is to eliminate the possibility of the presence of autocorrelation of residues; $\rho$ is the initial unit root test process, so that: $H_{0}: \rho-1, H_{1}:|\rho|<1$, under H0 the process has a stochastic tendency; and $\varepsilon_{t}$, is error structure, which is assumed to have zero mean, constant variance and absence of autocorrelation.

If a series is non-stationary, the stochastic trend can be eliminated through differentiation. For cases of estimation of VAR - Autoregressive Vector Model, containing non-stationary variables, it is possible to have stationary linear combinations for integrated variables of the same order, that is, long-term equilibrium relationships that must be included in the model to avoid errors specification [11].

In order to know the number of cointegrated vectors, it is important to highlight the significance of the characteristic roots of $\pi^{1}$. The test to check the number of characteristic roots that are significantly different from zero is performed using the statistic $\lambda_{\text {trace }}$ :

$$
\lambda_{\text {trace }}(r)=-T \sum_{i=r+1}^{n} \ln \left(1-\hat{\lambda}_{i}\right)
$$

On what $\mathrm{T}$, is the number of observations used in the adjustment, $\stackrel{\wedge}{\lambda}$ are the estimated values of the characteristic roots obtained by estimating the matrix $\pi$. To check the number of lags required in the multiequation model, the SC (Schwarz Criterion) criterion is used. Thus, the determination of the number of cointegration serves as a basis to define whether the model to be estimated will be a VAR or VEC - Error Correction Model, in the study in question a VEC was estimated, considering the number of cointegration (see table 2).

Theoretically, the tested model can be defined as:

$$
\text { Ibov }_{t}=f\left(\text { Lvale }_{t}, \text { Lusd }_{t}, \text { Lbrent }_{t}, \text { Lpetro }_{t}\right)
$$

On what:

$I b o v_{t}=$ Ibovespa indicator points in period $\mathrm{t}$,

Lvale $_{t}=$ Spot price of Vale3 at time t,

Lusd $_{t}=$ Exchange rate USD/Brazilian Real at the time t,

Lbrent $t_{t}=$ Quotation of the future Brent at time $\mathrm{t}$,

Lpetro $_{t}=$ Spot price of petr 4 at time $t$,

\footnotetext{
${ }^{1}$ The rank of $\pi$ is equal to the number of cointegrated vectors. Suposing that $\pi=0$, there are no linear combinations of $\left\{x_{i t}\right\}$ that are stationary and therefore the variables are not cointegrated. 
The analysis time ranges from 01/02/2018 to 05/15/2020, considering a series of daily information data. The data collected are based on Economática [10] and, to estimate the model, the data were transformed into logarithms. As a basic hypothesis, the importance of two assets vale 3 and petr4 have in the formation of the Ibovespa indicator is considered, consequently, variations in prices should strongly influence the variation of the indicator. Specifically, it is assumed that the quotations of domestic and international oil prices, iron ore prices and foreign currency prices encourage strong results on the future price of the Ibovespa index. In addition, the dollar as a commodity should serve as a parameter to measure the intentions of foreign investment in the domestic market, which should be reflected in the stock market indicator.

\section{A. Definition of the number of model lags and cointegration}

When working with time series data, it is important to analyze stationarity. The stationarity condition is important in order to guarantee an estimate of the equation to be estimated. It is common to observe that economic series tend, in some cases, to structural breaks which cause them to have a unit root during the analysis time. Therefore, the unit root test was initially performed for each of the variables used in the model defined to explain the variations in the Ibovespa indicator.

The variables described in equation 3 are LIbov, LVale, LUsd, LBrent, LPetro. For the sake of analysis, the data from each of the series used were transformed into logarithms in such a way as to reduce the variance and facilitate its interpretation. Initially, the series were analyzed at the level. At the level, the variables LVale, LUsd did not show statistical significance to state that there is a unit root, already for the variables LIbov, LBrent, LPetro that one cannot reject the hypothesis that the series under analysis have a unit root. The determined values were estimated with the version of constant and trend. The number of lags $(p)$ of the DF-GLS test, defined for each of the variables inserted in the estimated model, was determined according to the Akaike MAIC information criterion.

Thus, as mentioned in the previous paragraph, it turns out that the series under analysis are co-integrated with different orders. To facilitate the estimation process, we proceeded to work with the series in the first difference, since most of the series is stationary in the first difference, the idea is to standardize the series.

To obtain the number of lags for the analysis of cointegration and considering the integrated series of order I (1), the Johansen procedure was used, from the specification of a VAR model. For the identification of the number of lags in the VAR model, the Schwarz criterion was used, which according to Enders [11], is the most parsimonious. Table 2 shows that the Schwarz criterion identifies the existence of only one lag.

Table 2 - Definition of the number of lags in the VAR model based on the Schwarz and Hannan-Quinn criterion.

\begin{tabular}{llll}
\hline Lags & Akaike & Hannan-Quinn & Schwarz \\
\hline 0 & -8.0872 & -8.0725 & -8.0496 \\
1 & -25.3271 & $-25.2392 *$ & $-25.1017^{*}$ \\
2 & -25.3572 & -25.1961 & -24.9440 \\
3 & -25.3302 & -25.0959 & -24.7292 \\
4 & $-25.4152^{*}$ & -25.1077 & -24.6264 \\
\hline
\end{tabular}

* Minimum value of each criterion used in choosing the number of lags.

Source: Research results

The next step was to perform the cointegration test to test the existence of a long-term relationship between the variables, for which Johansen's cointegration test $[19,20]$ was applied, specifically the trace statistics. This procedure was chosen due to the multivariate analysis of the time series and the possibility of verifying the existence of more than one cointegration vector. It is noteworthy that, to apply the Johansen test, the series must be standardized in the same order of integration.

The table 3 shows the results of the Johansen cointegration test for the estimated equation. By the statistical trace, it is observed that for the null hypothesis that the number $r$ of vectors is less than or equal to zero $(0)$, 
which is rejected in favor of the alternative hypothesis $r$ equal to one (1). Thus, the vector autoregression model must consider the existence of a cointegration vector. Therefore, a VEC (Vector Auto-Regression Model with Error Correction) must be estimated, to consider both short- and long-term aspects.

Table 3 - Maximal eigenvalue trace test for cointegration between model variables.

\begin{tabular}{llll} 
Hipótese Nula $\mathrm{H}_{\mathrm{O}}$ & \multicolumn{1}{c}{ Hipótese Alternativa $\mathrm{H}_{\mathrm{A}}$} & $\lambda$ Traço & Valores Críticos 5\% \\
\hline $\mathrm{R} \leq 3$ & $\mathrm{r}=4$ & 4.6715 & 12.25 \\
$\mathrm{R} \leq 2$ & $\mathrm{r}=3$ & 13.8722 & 25.32 \\
$\mathrm{R} \leq 1$ & $\mathrm{r}=2$ & 31.3782 & 42.44 \\
$\mathrm{R} \leq 0$ & $\mathrm{r}=1$ & $51.0393^{*}$ & 62.99 \\
\hline
\end{tabular}

* Significant at 5\% probability - critical values in (Osterwald \& Lenum, 1992).

Source: Research results.

\section{B. Result of the estimation of equation 3}

In table 4 shows the estimated results of VEC cointegration parameters. The coefficients denote the speed of short-term adjustment of the variables towards long-term equilibrium. Thus, if there is an imbalance in the short term, a high value of each coefficient indicates that the adjustment speed will be fast towards the long term equilibrium, otherwise a small value will indicate that the speed will be low and, consequently, the adjustment from a short-term imbalance situation to a long-term equilibrium situation will tend to be corrected slowly.

Still in Table 4, in terms of signs, there are two variables in positive and two negative signs. The effect of these variables indicates that an increase of $1 \%$ in the LVALE and LUSD quotation would have a positive and, therefore, appreciation effect in the indicator by $0.306 \%$ and $0.169 \%$, respectively. Conversely, an increase of $1 \%$ in the LBRENT and LPETRO quotation would have a negative effect and, therefore, would lower the value of the index.

These results may evidence the effects of past events that caused volatility in the stock market, such as the 2018 walker strike, the Joesley day effect, and Brent oil fluctuations resulting from excess supply. Linked to these events, in 2020 there was the oil trade war involving OPEC countries and Russia, also the covid-19 pandemic. Overall (for analysis time), the first quarter 2020 became the period in which the greatest effects linked to the system's risk affected the Ibovespa indicator most sharply, consequently, the prices of assets in the market were at a level below the average for the time under analysis. It is evident to observe that the calculated coefficients influence the indicator in several directions, given the sign of the indicator. In May 2020, for example, the price of iron ore appreciated rapidly with stimulus from the Chinese government, being one of the largest suppliers of the commodity, something that was priced by VALE3.

According to table 5, of Johansen's normalized restriction, an increase of $1 \%$ in Vale's quotations would cause an increase of $0.38 \%$ in the Ibovespa indicator in the long term, this shows that there is a significant positive effect, reinforced by the importance of this asset as part of the indicator portfolio.

A similar (positive) effect is observed with the dollar, although the effect of this coefficient shows an increase in the Ibovespa indicator, the economic reality reflects the opposite, with an ever higher exchange rate resulting from various behaviors, such as the political noise that has become common in recent years, the successive fall of the interest rate to historical minimum levels, which make investment in Brazil less attractive to foreign investors, an economic projection with a low potential GDP and a drop in commodity prices. In the last two variables of model, adverse effects are seen for Petro and Brent (taking as a proxy for domestic and international oil prices), for which variations of $1 \%$ in these two variables would shift the indicator downwards. 
Table 4 - VEC cointegration parameters, daily data. 02/01/2018-15/05/2020.

\begin{tabular}{|l|l|l|l|}
\hline Variable & Coefficient & Standard Error & P-value \\
\hline LVALE & 0.3062 & 0.0456 & 0.000 \\
\hline LUSD & 0.1691 & 0.0767 & 0.027 \\
\hline LBRENT & -0.1349 & 0.0274 & 0.000 \\
\hline LPETRO & -0.4163 & 0.0486 & 0.000 \\
\hline
\end{tabular}

Source: Research results.

Table 5 - Johansen standardization restriction, daily data. 02/01/2018-15/05/2020.

\begin{tabular}{|l|l|l|l|}
\hline Variable & Coefficient & Standard Error & P-value \\
\hline LOGIBOV & 1 & - & - \\
\hline LVALE & 0.3751 & 0.0472 & 0.000 \\
\hline LUSD & 0.0815 & 0.1165 & 0.449 \\
\hline LBRENT & -0.1475 & 0.0349 & 0.000 \\
\hline LPETRO & -0.4434 & 0.0371 & 0.000 \\
\hline
\end{tabular}

Source: Research results.

The Vector Auto-Regression method allows to obtain the response functions given an impulse (shock) in certain variables, such functions are important to analyze the evolution of the system variables in the face of unanticipated shocks. So, this section seeks to identify the effects of unanticipated shocks on the system variables for $\mathrm{k}=14$ days ahead, on the Ibovespa indicator.

Thus, figure 4 shows the accumulated responses of Ibovespa to an unanticipated shock of $1 \%$ in the independent variables. A shock of $1 \%$ in the variables LPETRO and LUSD would cause positive effects/appreciation of the Ibovespa indicator, and conversely, a shock of $1 \%$ in LVALE. Specifically, greater effects are seen in the relationship between the Ibovespa indicator and LUSD and LPETRO, thus, unexpected shocks in the price of domestic and international oil would induce a rapid appreciation of the index. This increase may be related to aspects that favor the commercialization of this commodity, such as, for example, the supply reduction agreement aimed at securing prices between oil producing countries. In the short term, Ibovespa does not show significant variation due to an unexpected shock in LBRENT. 
Response to Cholesky One S.D. Innovations \pm 2 S.E.

Response of LIBOV to LPETRO

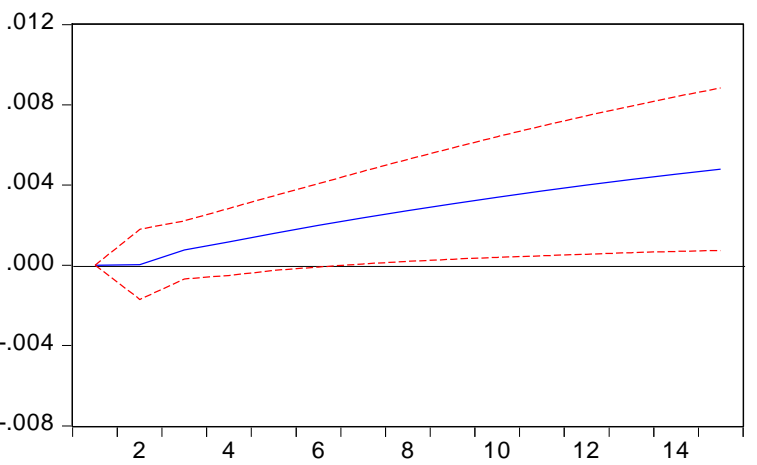

Response of LIBOV to LVALE

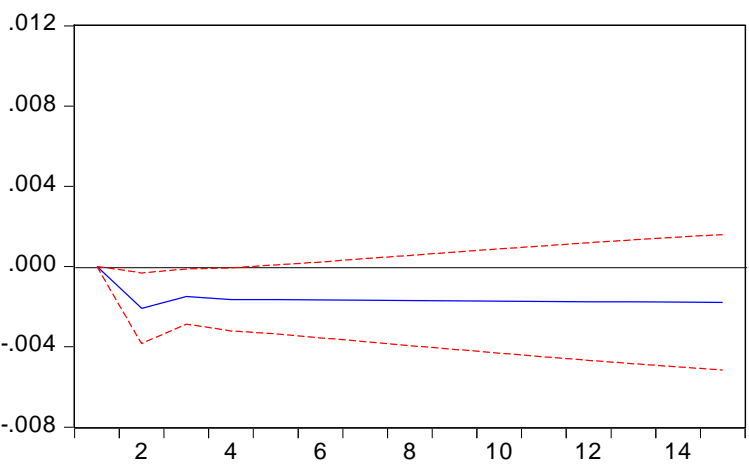

Response of LIBOV to LUSD

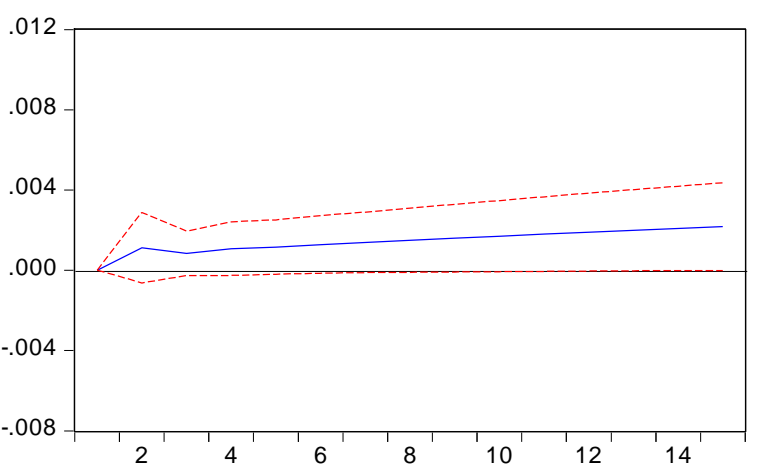

Response of LIBOV to LBRENT

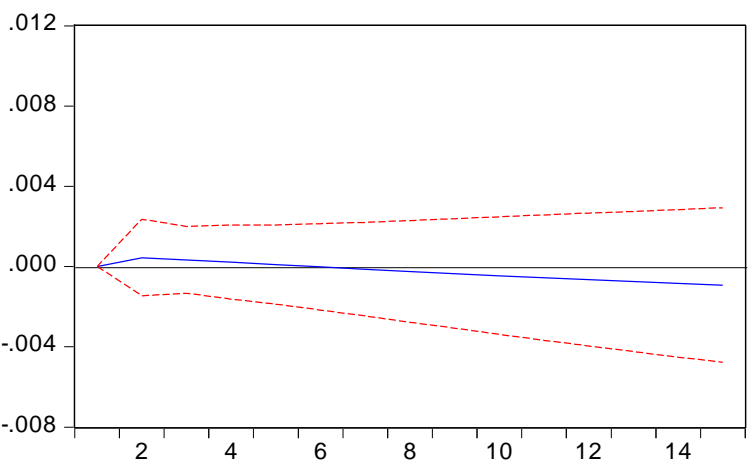

Fig. 4 - Impulse response function between the Ibovespa and the model variables.

Source: Research results

\section{CONCLUSIONS}

The economic theory holds that the stock market has a close relationship with the foreign exchange market, given that the return / appreciation of the foreign currency causes changes in company revenues and, consequently, this effect is passed on stock quotes. In addition to foreign currency, the study in question considers the prices of oil and iron ore. It is considered that the price of petr4 (domestic oil proxy) and Brent price (international oil proxy), the price of vale3 (domestic iron ore proxy) and the dollar analyzed as a commodity are determining variables to try to explain the direction and / or variation of the index. The choice of these variables is reinforced by the weight that petr 4 and vale 3 assets have in the composition of the Ibovespa Indicator portfolio, with a percentage of $5.68 \%$ and $11.14 \%$, respectively, of a total of 75 assets.

Thus, the study aimed to analyze the variation of the Ibovespa indicator for the period from 2018 to 2020 and to explain the magnitude of the effect of the determining variables. It is considered a period of high growth of the Ibovespa indicator from 2018 until the middle of the second quarter of 2020, with the covid-19 pandemic and the oil price war. Besides that, the idea focuses on analyzing/predicting the future (through the impulse response function) of the indicator's direction based on the variables mentioned in the study and the extent to which these variables can explain the indicator's variation.

The results support the hypothesis of the importance of iron ore prices (proxy vale3), as well as, the oil as commodities determinants the variation/direction of the Ibovespa indicator, a fact observed by the statistical significance obtained in Tables 1 and 2, something not verified with the dollar quotation for a long-term relationship. Considering the Brazilian experience in relation to the dollar exchange rate, with increasing rates in recent years, a statistically significant long-term relationship was expected as a possible predictor of the behavior of the Ibovespa index. Coupled with this behavior, there is the effect of the covid-19 pandemic, which 
weighs on economic performance or on the stock market indicator. In addition, in the third month of 2020, the prices of the main shares in the Brazilian scenario were below the average for the study time.

Analyzing the prices of iron ore, the rapid appreciation of the asset in the international market (first quarter of 2020) and the appreciation of the shares of vale 3 , it contradicts the appreciation of the Ibovespa indicator in the short term. This behavior can partially explain the adverse effect of short-term shocks of the assets on the Ibovespa.

Eventually, the recovery of the indicator is driven by the appreciation of iron ore, as well as the price of oil. However, other events must be incorporated (cannot be neglected in the discussion) which interfere with the performance of the economy, mainly, stimuli aimed at the recovery of the economy, and of the main world economies with which Brazil has a strong relationship of trade, such is the case for the United States and China.

\section{ACKNOWLEDGMENT}

The authors would like to thank the Federal University of Mato Grosso do Sul - Brazil, for their financial support for the publication of the article.

\section{REFERENCES}

[1] Alqahtani, A. et al. Impact of news-based equity market volatility on international stock markets. Journal of Applied Economics. Volume 23, Issue 1, 1 January 2020, Pages 224-234. DOI: 10.1080/15140326.2020.1729571.

[2] Angelous. R. K. Foreign Direct Investment and Spillover Effects in Africa: An Empirical Review. International Journal of Science and Management Studies (IJSMS), Volume: 02 Issue: 03 May to June 2019

[3] Bernal-Ponce, la; Castillo-Ramírez, ce; Venegas-Martínez, F. Impact of exchange rate derivatives on stocks in emerging markets. Journal of Business Economics and Management, v. 21, n. 2, pág. 610-626, 10 de abril de 2020.

[4] B3. Bolsa, Brasil, Balcão: Carteira Teórica do Ibovespa válida para 25/05/20. B3. Disponível em: http://www.b3.com.br/pt_br/market-data-e-indices/indices/indices-amplos/indice-ibovespa-ibovespa-composicao-da-carteira.htm. Access em: 25 maio 2020 .

[5] B3. (org.). Relações com Investidores. Available in: https://ri.b3.com.br/pt-br/b3/historico/. Access in: 24 may 2020.

[6] CVM. Comissão de Valores Mobiliários. O mercado de valores mobiliários brasileiro (3 ed.). Rio de Janeiro: Comissão de Valores Mobiliários, 2014.

[7] Debata, B.; Mahakud, J. Interdependence between Monetary Policy and Stock Liquidity: A Panel VAR Approach. Margin. Volume 12, Issue 4, 1 November 2018, Pages 387-413. DOI: 10.1177/0973801018786270

[8] Dickey, D.A.; Fuller, W.A. Distribution of the estimator for auto-regressive time series with a unit root. Journal of the American Statistical Association, Alexandria, v. 74, p. 427-431, 1979.

[9] Dickey, D.A.; Fuller, W.A. Likelihood ratio statistics for autoregressive time series with a unit root. Econométrica, Chicago, v. 49, n. 4, p. 1057-1072, July 1981.

[10] Economatica. database. Available in: https://economatica.com/. Access in 27 may, 2020

[11] Enders, W. Applied Econometric Time Series. Wiley, 4th Edition. 2014. 496p.

[12] Feijó, C. A. et al. Para entender a conjuntura econômica. Barueri, SP: Manole, 2011

[13] Fuller, W.A. Introduction to statistical time series. New York: John Wiley \& Sons, 1976. 480 p.

[14] Gaertner, F B.; HoopeS, J. L.; Maydew, E. L. Efeitos de Riqueza do Acionista da Tributação do Ajuste da Fronteira. Research document of Kenan Institute of Private Enterprise, n. 18-2, 2019.

[15] Gertler, M.; Hubbard, R. G.; Kashyap, A. Interest rate spreads, credit constraints, and investment fluctuations: an empirical investigation. In: Financial markets and financial crises. University of Chicago Press, p. 11-32, 1990.

[16] Holmes, Mark J. \& Otero, Jesús, 2019. "Re-examining the movements of crude oil spot and futures prices over time. Energy Economics, Elsevier, vol. 82(C), pages 224-236.

[17] IMF - International Monetary Fund. Global Financial Stability Amid Covid - 19 Pandemic. 2020. Disponível em: <https://soundcloud.com/imf-podcasts/global-financial-stability-2>. Access in 27/04/2020. 
[18] IMF - International Monetary Fund. 2019 em revisão: Cinco gráficos que explicam a economia mundial. 2019. Disponível em: <https://www.imf.org/pt/News/Articles/2019/12/18/blog121819-2019-in-review-five-charts>. Acsess in 27/04/2020.

[19] Johansen, S. Likelihood-base inference in cointegrated vetor auto-regressive models. Oxford: Oxford University Press, 1995. 267p.

[20] Johansen, S. 1988. Statistical analisys of cointegration vectors. Journal of Economics Dynamics and Control, Frankfurt, v. 12, p. 231254,1988

[21] Khan, R.; Rehman, H. \& Ali, Rokia. (2016). Volatility in stock market price and exchange rate: The case study of bombay stock exchange. International Journal of Economic Perspectives. Volume 10, Issue 2, 2016, Pages 110-116

[22] MacieL, Leandro et al. Impacto dos contratos futuros do Ibovespa na volatilidade dos índices de ações no Brasil: uma análise na crise do subprime. Estudos Econômicos (São Paulo), v. 42, n. 4, p. 801-825, 2012.

[23] Montes, Gabriel Caldas; Tiberto, Bruno Pires. Macroeconomic environment, country risk and stock market performance: Evidence for Brazil. Economic Modelling, v. 29, n. 5, p. 1666-1678, 2012.

[24] Pires, D. L. Análise do impacto da volatilidade cambial sobre o fluxo comercial entre Brasil, China e EUA (2000-2017). Dissertação (mestrado acadêmico) - Universidade Federal de Juiz de Fora, Faculdade de Economia. Programa de Pós-Graduação em Economia, 2019.

[25] Robiyanto, R., Santoso, M A. \& Apriani, D. R. A. \& Harijono, H. 2019. "The Indonesia Stock Exchange and Its Dynamics: An Analysis of the Effect of Macroeconomic Variables. Montenegrin Journal of Economics, Economic Laboratory for Transition Research (ELIT), vol. 15(4), pages 59-73.

[26] Rujirarangsan, K., \& Chancharat, S. (2019). The Impact of Coup d'états on the Relationship between Stock Market and Exchange Rate: Evidence from Thailand. Academic Journal of Interdisciplinary Studies, 8(3), 113

[27] Santana, Henrique Nogueira et al. 20 Anos de Real: uma análise da relação entre câmbio, inflação, taxa de juros e o Ibovespa. Revista Gestão \& Tecnologia, v. 18, n. 2, p. 44-69, 2018.

[28] Shahrestani, P.; Rafei, M. The impact of oil price shocks on Tehran Stock Exchange returns: Application of the Markov switching vector autoregressive models. Resources Policy. Volume 65, March 2020. DOI: 10.1016/j.resourpol.2020.101579

[29] Singhania, M.; Saini, N. Fii, stock exchange return, and the leverage effect: Evidence from India. Journal of Wealth Management. Volume 19, Issue 1, Summer 2016, Pages 103-119. DOI: 10.3905/jwm.2016.19.1.103

[30] Silva, J. P. et al. Qualidade do lucro versus governança corporativa: uma análise das companhias de utilidade pública listadas na B3. Contabilidade Vista \& Revista, v. 29, n. 1, p. 48-76, 2018.

[31] Talbi, Marwa \& de Peretti, Christian \& Belkacem, Lotfi, 2020. "Dynamics and causality in distribution between spot and future precious metals: A copula approach," Resources Policy, Elsevier, vol. 66(C).

[32] Uzo-peters, A.; Laniran, T.; Adenikinju, A. Brent prices and oil stock behaviors: evidence from Nigerian listed oil stocks. Financial Innovation. Volume 4, Issue 1, 1 December 2018, Article number 8. DOI: 10.1186/s40854-018-0092-2. 